\title{
An oceanographic, meteorological, and biological 'perfect storm' yields a massive fish kill
}

\author{
Beth A. Stauffer ${ }^{1,3, *}$, Alyssa G. Gellene ${ }^{1}$, Astrid Schnetzer ${ }^{1,4}$, Erica L. Seubert ${ }^{1}$, \\ Carl Oberg ${ }^{2}$, Gaurav S. Sukhatme ${ }^{2}$, David A. Caron ${ }^{1}$ \\ ${ }^{1}$ Department of Biological Sciences and ${ }^{2}$ Department of Computer Science, University of Southern California, Los Angeles, \\ California 90089, USA \\ ${ }^{3}$ Present address: Lamont-Doherty Earth Observatory at Columbia University, Biology and Paleo-Environment, Palisades, \\ New York 10964, USA \\ ${ }^{4}$ Present address: Department of Marine, Earth, and Atmospheric Sciences, North Carolina State University, Raleigh, \\ North Carolina 27695, USA
}

\begin{abstract}
Mass mortality events are ephemeral phenomena in marine ecosystems resulting from anthropogenically enhanced and natural processes. A fish kill in King Harbor, Redondo Beach, California, USA, in March 2011 killed $\sim 1.54 \times 10^{5} \mathrm{~kg}$ of fish and garnered international attention as a marine system out of balance. Here, we present data collected prior to, during, and following the event that describe the oceanographic conditions preceding the event, spatial extent of hypoxia (dissolved oxygen $<1.4 \mathrm{ml} \mathrm{l}^{-1}$ ), and subsequent recovery of the harbor. In situ sensors within the harbor revealed rapid decreases in dissolved oxygen in surface waters from 7 to 9 March 2011, coincident with the mortality event on 8 March. Continuous observations provided evidence that respiration of a large population of fish within the harbor, potentially exacerbated by an incursion of upwelled low-oxygen water, resulted in significant oxygen reduction in the harbor and ultimately caused mortality of the fish population. The hydrodynamically constrained northern basin transitioned to nearly anoxic conditions, while spatially variable hypoxia was observed throughout the harbor and adjacent bay for $>10 \mathrm{~d}$ following the event. Initial recovery of dissolved oxygen in the harbor was facilitated by storm-mediated mixing. No connection was apparent between increased algal biomass or phycotoxins within the harbor and the mortality event, although the fish showed evidence of prior exposure to the algal neurotoxin domoic acid. Our findings underscore the essential role of ocean observing and rapid response in the study of these events and the role that oceanographic processes play in hypoxia-driven fish mortalities. Alterations in upwelling regimes as a consequence of climate change are likely to further increase the frequency and magnitude of upwelling-driven hypoxia and mortality events.
\end{abstract}

KEY WORDS: Fish kill · Hypoxia · Nearshore embayment $\cdot$ Upwelling $\cdot$ Mixing

Resale or republication not permitted without written consent of the publisher

\section{INTRODUCTION}

Massive fish mortalities occur in marine and freshwater ecosystems (Bell \& Eggleston 2005, MartiCardona et al. 2008, Palsson et al. 2008, Gannon et al. 2009, Ruuhijarvi et al. 2010) as a result of anthropogenically enhanced and natural processes (Kemp et al. 2005, Diaz \& Rosenberg 2008, Thronson \& Quigg 2008, La \& Cooke 2011), and the reported frequency and range of such events has increased in recent decades both in the USA (Grantham et al. 2004, La \& Cooke 2011) and globally (Lugg 2000). The term 'fish kill' is loosely defined in the literature, but Lugg (2000) suggested a definition of a sudden and unexpected mass mortality of wild or cultured fish. Fish kills may be small in spatial scale and magnitude, as documented by Hoyer et al. (2009), who observed that the vast majority $(81 \%)$ of fish kills between 1984 and 2002 in Florida canals, rivers, and lakes totaled $<1000$ dead fish. In contrast, fish kills 
may also represent a severe depletion of local fish populations, and Lowe et al. (1991) documented 86 individual mortality events in which $>1$ million fish were killed from 1980 to 1989 nationwide in the USA.

It is often difficult to directly attribute causation to mortality events due to their patchiness in time and space and potential forcing by multiple underlying processes; indeed, the complexity of such events can lead to great debate about the mechanisms underlying mass mortality events (e.g. Paerl et al. 1998, Burkholder et al. 1999). Surpassing the temperature limits of aquatic species has been implicated in some seasonally localized mortalities (Bohnsack 1983, Hoyer et al. 2009, Balayla et al. 2010). Phytoplankton biomass can also be a causative factor behind many mass mortality events, either through biomass accumulation and consequent oxygen depletion during the night or termination of a bloom (Paerl et al. 1998, Brownlee et al. 2005, Anderson et al. 2008, Glibert et al. 2008, McInnes \& Quigg 2010) or through the production of ichthyotoxic compounds, such as those produced by the dinoflagellates Cochlodinium polykrikoides (Kim et al. 1999, Mulholland et al. 2009) and Pfisteria sp. (Burkholder et al. 1995) or the haptophyte Prymnesium parvum (Southard et al. 2010). Eutrophication has been shown to enhance growth of phytoplankton and greatly increase biological oxygen demand, especially in estuaries and inland seas (Kemp et al. 2005, Thronson \& Quigg 2008), and it is likely that eutrophication, increased phytoplankton biomass, and production of toxic compounds may act together as a synergistic causative mechanism in many mortality events. Finally, particularly in confined aquaculture populations, parasite infections may also play a role in large-scale fish mortality events (Ogawa 2002).

The sociological impacts of fish mortalities are numerous and include loss of revenue to aquaculture and fishing ventures (Koehn 2004) in addition to reductions in tourism-based economies (Backer 2009) and recreational opportunities (Oh \& Ditton 2005). Some species that succumb to mass mortality events are high-level consumers, such as the Murray cod in Australia that is a keystone predator in its habitat (Koehn 2004), and their removal can have cascading effects throughout lower trophic levels (Ruuhijarvi et al. 2010). Coastal planktivorous fish, such as sardine and anchovy, provide a fundamental link between producers and higher trophic levels, and changes in their overall abundance and distribution reverberate through primary producer, zooplankton, and other fish communities (Chavez et al. 2003) while also negatively affecting their own consumers, such as seabirds (McLeay et al. 2009, Wagner \& Boersma 2011).

Here, we present highly resolved spatial and temporal data from King Harbor, City of Redondo Beach, California, USA, that describes the physicochemical conditions leading up to a massive fish kill on 8 March 2011, the spatial and temporal extent of hypoxia throughout the harbor system following the event, and the ultimate recovery of the harbor water column. Data collected using in situ sensors, an autonomous underwater vehicle, and traditional sampling prior to, during, and after the mortality event revealed low algal biomass, indicating no involvement of algae, toxic or otherwise. Instead, a rapid decrease in dissolved oxygen was observed simultaneous with the reported mortality as a consequence of respiration of extremely high fish biomass and an input of upwelled, potentially low-oxygen water from the local coastal environment.

\section{MATERIALS AND METHODS}

\section{Study site}

King Harbor is a commercial and recreational harbor located within the city of Redondo Beach, California in southeastern Santa Monica Bay (SM Bay; Fig. 1a). The harbor is semi-enclosed by a rubble breakwater and consists of 2 marina basins (northern and southern) joined by an outer harbor region to the west, which in turn provides connectivity to SM Bay. The southern opening of the breakwater provides the only direct connection of the outer harbor region to the coastal ocean, and the northern and southern internal basins have connections only to the outer harbor region. Water depths within the marina basins range from 3.5 to $6 \mathrm{~m}$, while the outer harbor slopes from $7 \mathrm{~m}$ near the entrance to the northern basin to $10 \mathrm{~m}$ at the mouth of the harbor. King Harbor experiences a mixed tide with both diurnal and semi-diurnal components, and data collected in 2008 with an acoustic Doppler current profiler (Sontek Argonaut $\mathrm{XR}$ ) suggest that tidal ranges of $1.5 \mathrm{~m}$ are common. In 2005, King Harbor suffered a significant fish mortality event concomitant with a harbor red tide of unknown composition and a prolonged regional bloom of the red tide dinoflagellate Lingulodinium polyedrum (Barboza \& Weiss 2011). In response to that incident, continuous monitoring of harbor water quality began in 2006 using an embedded sensor network at locations within the marina basins. 


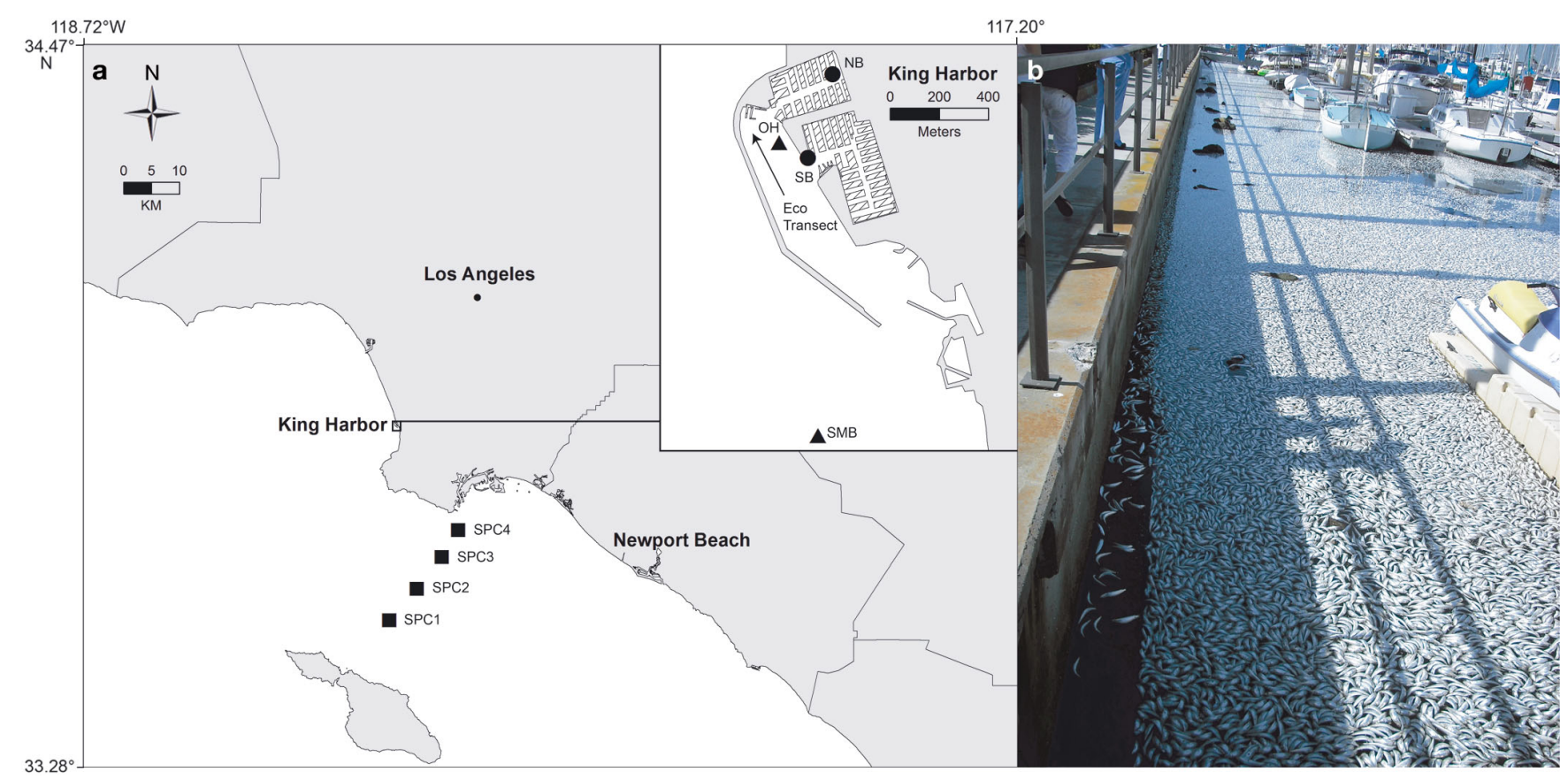

Fig. 1. (a) Southern California Bight and (inset) King Harbor.

Northern and southern basin (NB, SB) stations with continuous sensor sampling; $\mathbf{\Delta}$ : outer harbor $(\mathrm{OH})$ and Santa Monica Bay (SMB) stations sampled vertically following the mortality event (8 March); $\mathbf{E}$ : phycotoxin and chlorophyll sampling locations in the San Pedro Channel (SPC); arrow: the EcoMapper AUV transect ('Eco Transect') on 25 March. (b) Dead fish along the seawall of the northern basin

\section{Sensors}

Water quality monitor sensors (WQM; Wetlabs) were factory-calibrated prior to deployment (November 2010) and deployed at 0.5 to $0.75 \mathrm{~m}$ depth from floating docks at the northern and southern basin locations (Fig. 1). The sensors were programmed to log temperature $\left({ }^{\circ} \mathrm{C}\right)$, salinity (PSU), dissolved oxygen $\left(\mathrm{ml} \mathrm{l}^{-1}\right)$, and chlorophyll a fluorescence at $695 \mathrm{~nm}\left(\mu \mathrm{g} \mathrm{l}^{-1}\right)$ for $10 \mathrm{~s}$ at 30 min intervals. Each WQM was equipped with a copper BioWiper (WetLabs) over the optical sensors and bleach injection system (BLIS) module to minimize the effects of biofouling.

A laboratory-calibrated datasonde (DS5; Hach Hydrolab) was used for vertical profiling at the northern basin, southern basin, outer harbor, and SM Bay locations throughout the period immediately following the fish kill. Following equilibration just below the surface $(<10 \mathrm{~cm})$, the DS5 sensor was slowly lowered to allow for multiple readings per depth (sampling rate $=1 \mathrm{~s}^{-1}$ ).

The DS5 sensor was calibrated using standard conductivity solutions (Hach) and a serially diluted phytoplankton culture mixture consisting of 1 locally isolated culture each from the Dinophyceae, Prasino- phyceae, Bacillariophyceae, and Raphidophyceae (Cetinic et al. 2009). Samples for extracted chlorophyll a analysis were processed according to the protocols of Strickland \& Parsons (1972) and run in triplicate with $5 \% \mathrm{HCl}$ acidification on a laboratory fluorometer (Turner Designs TD-700). Standardized chlorophyll fluorescence was further normalized by regression of sensor values to extracted chlorophyll a values from several whole seawater (WSW) samples taken at each location during the study period $\left(\mathrm{R}^{2} \geq\right.$ 0.80). The DS5 dissolved oxygen sensor was calibrated on a weekly basis using air-saturated water, as directed by the manufacturer.

WQM data from the northern and southern basin locations were normalized to overlapping data from the DS5 vertical profiles. Least-squared regression of temperature, chlorophyll, and dissolved oxygen measurements across the 2 sensor types were highly consistent $\left(R^{2}>0.89\right)$. Regression of salinity data in the northern $\left(R^{2}=0.65\right)$ and southern basins $\left(R^{2}=\right.$ 0.88 ) revealed a strong effect of just 2 data points for which the WQM-measured salinity was $~ 0.4$ units higher than that measured by the DS5. All continuous sensor data were converted to equivalent DS5 units and are presented as such throughout the rest of the manuscript. 


\section{Autonomous oxygen profiles}

An EcoMapper (YSI) autonomous underwater vehicle (AUV) was deployed on 25 March to further characterize the spatial distribution of dissolved oxygen within the harbor ecosystem. A south-to-north vertically undulating transect from 0 to $4 \mathrm{~m}$ depth in the outer harbor ( $315 \mathrm{~m}$ horizontally; Fig. 1) was conducted by the vehicle. An electrode-free, optical dissolved oxygen sensor (6150 ROX, YSI) was calibrated to air-saturated water (as described above) before each deployment and had an operating range of 0 to $35 \mathrm{ml} \mathrm{l}^{-1}$.

\section{Meteorological data}

Wind speed and barometric pressure data were obtained from the National Data Buoy Center (www.ndbc.noaa.gov) for Stn 46025 in the Santa Monica Basin $\left(33.749^{\circ} \mathrm{N}, 119.053^{\circ} \mathrm{W}\right)$ and averaged to $6 \mathrm{~h}$ intervals. Sea surface temperature $(<1 \mathrm{~m}$ depth) was obtained through the Coastal Data Information Program (http://cdip.ucsd.edu/) for buoy 028 in SM Bay $\left(33.855^{\circ} \mathrm{N}, 118.633^{\circ} \mathrm{W}\right)$ and the Southern California Coastal Ocean Observing System (http:// sccoos.org/) from an automated station ( 2 m depth) located at the Santa Monica Pier $\left(34.008^{\circ} \mathrm{N}\right.$, $118.499^{\circ} \mathrm{W}$ ). Daily values for the upwelling index anomaly, based on surface pressure gradients, were acquired for the Pacific Fisheries Environmental Laboratory for the $33^{\circ} \mathrm{N}$ region of Southern California (http://las.pfeg.noaa.gov). Averaged daily rainfall data was accessed via the National Climatic Data Center (NOAA; www.ncdc.noaa.gov/) for Stn 045114 located at the Los Angeles International Airport $\left(33.933^{\circ} \mathrm{N}, 118.383^{\circ} \mathrm{W}\right)$.

\section{Toxin analyses}

Near-surface $(<0.5 \mathrm{~m})$ WSW samples were collected at each study site into acid-washed polycarbonate bottles and kept cool and out of direct sunlight until processing within 3 to $4 \mathrm{~h}$ of collection. Weekly samples from the northern and southern basins were analyzed for domoic acid and saxitoxin from 8 February to $8 \mathrm{March}$, and samples from all 3 harbor locations (including the outer harbor) were analyzed from 10, 11, and 15 March. Surface WSW samples for domoic acid were collected and analyzed from sites in SM Bay and the San Pedro Channel (SPC; Fig. 1) on 9, 11, and 15 March. Volumes ranging from 150 to
$200 \mathrm{ml}$ were filtered onto GFFs for particulate toxin analyses, and the corresponding filtrates were reserved for determination of dissolved toxins. Fish were also collected for toxin analysis on 8 March from both the northern and southern basins. All samples were stored at $-20^{\circ} \mathrm{C}$ until analysis, within $\sim 2 \mathrm{mo}$ of collection.

Analyses of GFF-filtered seawater samples for phycotoxins were performed using enzyme-linked immunosorbent assays test kits for particulate and dissolved domoic acid (Mercury Science; Litaker et al. 2008) and particulate saxitoxins (Abraxis). Particulate domoic acid and saxitoxin analyses of whole fish samples were performed by extraction of $2 \mathrm{~g}$ of whole fish sample or 0.02 to $0.7 \mathrm{~g}$ of fish stomach. Limits of detection for particulate domoic acid were $0.02 \mathrm{ng} \mathrm{ml}^{-1}$ (WSW, $150 \mathrm{ml}$ ), $0.004 \mu \mathrm{g} \mathrm{g}^{-1}$ body weight (whole fish, $2 \mathrm{~g}$ ), and 0.01 to $0.4 \mu \mathrm{g} \mathrm{g}^{-1}$ body weight (fish stomachs, variable quantities). Dissolved domoic acid was resolved to a limit of detection of $0.2 \mathrm{ng} \mathrm{ml}^{-1}$. The limits of detection for particulate saxitoxin were $0.004 \mathrm{ng} \mathrm{ml}^{-1}$ (WSW, $150 \mathrm{ml}$ ) and $7.5 \times$ $10^{-4} \mathrm{\mu g} \mathrm{g}^{-1}$ body weight (whole fish, $2 \mathrm{~g}$ ).

\section{RESULTS}

On the morning of 8 March 2011, large numbers of dead fish in King Harbor, mainly Pacific sardine Sardinops sagax, were reported by local residents and through the local media (Barboza \& Weiss 2011). Fish biomass was concentrated overwhelmingly in the northern basin (Fig. 1b), with far fewer dead individuals observed in the southern basin. In total, $1.54 \times 10^{5} \mathrm{~kg}$ of fish was removed from the harbor (B. Workman, City Manager, City of Redondo Beach, pers. comm.), or $\sim 1.25$ million fish.

Surface seawater temperatures within the harbor were 15 to $16^{\circ} \mathrm{C}$ (Fig. 2a), salinity varied from 32.0 to 33.3 PSU (Fig. 2b), and dissolved oxygen averaged 3.1 and $3.9 \mathrm{ml} \mathrm{l}^{-1}$ in the northern and southern basins, respectively, for several days immediately preceding the fish kill (Fig. 2c). From May 2010 to June 2011, average dissolved oxygen concentrations at the northern and southern basin locations were 4.3 and $4.2 \mathrm{ml} \mathrm{l}^{-1}$, respectively. Exclusion of data from the month of March 2011 increases these mean concentrations to 4.6 and $4.3 \mathrm{ml} \mathrm{l}^{-1}$, respectively. Three stepwise decreases in dissolved oxygen were recorded from 7 to 9 March (Fig. 2f), with slight recoveries during each day, presumably a result of tidal flushing and/or photosynthetically mediated oxygen production, followed by rapid depletions in the late evening 

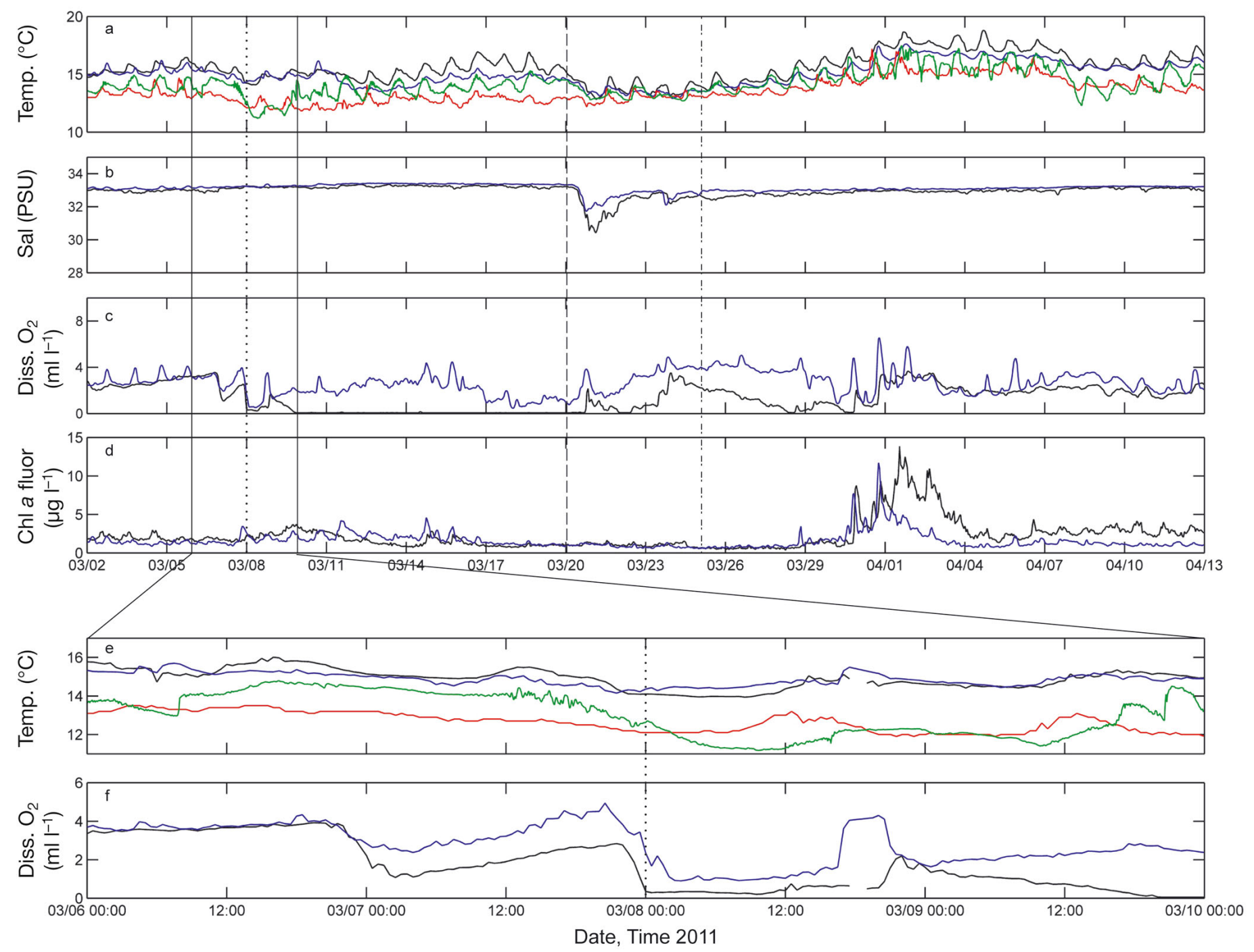

Fig. 2. Time-series data from the upper $1 \mathrm{~m}$ at northern (black) and southern (blue) basin locations for the period from (a-d) 2 March to 13 April and (e-f) 6 to 10 March. (a,e) Temperature, (b) salinity, (c,f) dissolved oxygen, and (d) chlorophyll a fluorescence data represent values binned to 30 min intervals. (a,e) Temperature data from (red) Santa Monica (SM) Bay and (green) SM Pier are also presented. Solid vertical black lines indicate the period shown at higher resolution (e-f). The vertical black dotted, dashed, and dot-dashed lines indicate midnight 8 March (the first reported day of fish mortality) initiation of the storm event on 20 to 21 March as indicated by (b) decreased salinity, and the date of the AUV transect (25 March), respectively

hours (Fig. 2f). Dissolved oxygen in the northern basin decreased from 3.9 to $1 \mathrm{ml} \mathrm{l}^{-1}$ in the pre-dawn hours of 7 March and then plummeted to $<0.2 \mathrm{ml} \mathrm{l}^{-1}$ by midnight on 8 March. This extreme hypoxia persisted for $10 \mathrm{~d}$ in the northern basin until the evening of 20 March. Dissolved oxygen concentrations in the southern basin never fell to the levels observed in the northern basin in the lead-up to the fish kill. After 9 March, dissolved oxygen continued to be highly variable but largely $>1 \mathrm{ml} \mathrm{l}^{-1}$ (Fig. 2c).

Depth-resolved sensing conducted in King Harbor and the adjacent bay during and immediately following the event revealed a stratified water column both within and outside of the harbor during the initial weeks of the fish kill event (Fig. 3). Consistently lower concentrations of dissolved oxygen were observed in the northern basin than at other locations both within the harbor or in SM Bay (Fig. 3). Values in the northern basin were consistently $\leq 0.1 \mathrm{ml} \mathrm{l}^{-1}$ throughout the water column from 8 to 20 March. Dissolved oxygen in the southern basin and outer harbor showed measurable near-bottom values until $10 \mathrm{March}$, when those locations also became hypoxic throughout the water column (Fig. 3). Oxygen concentrations in surface waters outside the harbor were relatively high during this period, but values were 


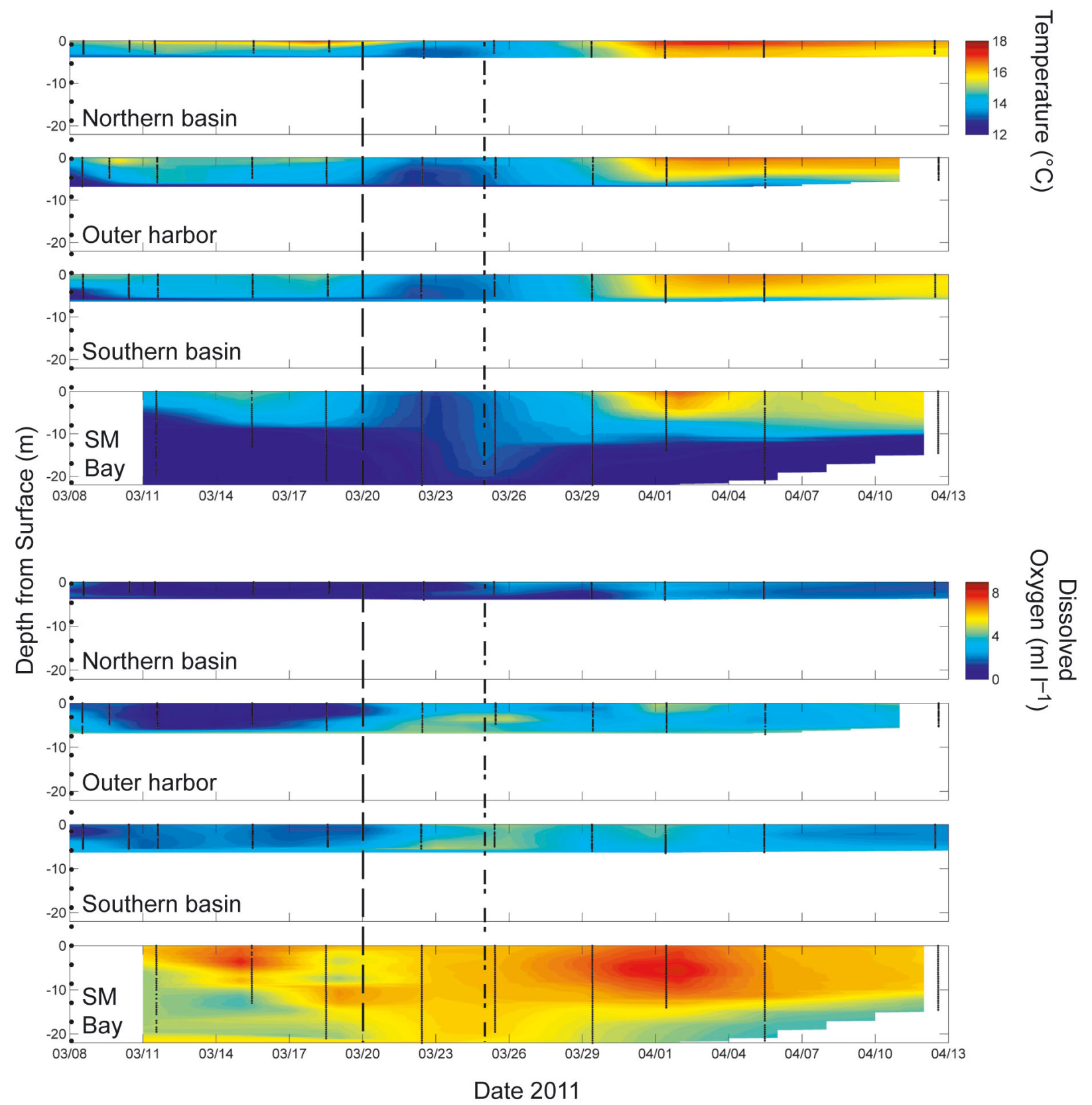

Fig. 3. Depth-resolved temporal evolution of (upper plots) thermal stratification and (lower plots) hypoxia from 8 March to 13 April at the northern basin, outer harbor, southern basin, and Santa Monica (SM) Bay locations. Contours are based on vertical profiles completed approximately every 3 to $4 \mathrm{~d}$ and interpolated at $1 \mathrm{~d}$ intervals. The vertical black dotted, dashed, and dot-dashed lines indicate the first reported day of fish mortality (8 March, coincident with left $y$-axis), initiation of the storm-mediated mixing event on 20 to $21 \mathrm{March}$, and the AUV transect on $25 \mathrm{March}$, respectively. $\bullet$ : vertical profile data points

markedly lower in the adjacent SM Bay below $5 \mathrm{~m}$, relative to values in surface waters at this location, from 11 to 15 March (Fig. 3), several days after the northern basin and outer harbor locations became acutely hypoxic. Initial recovery of dissolved oxygen within King Harbor was facilitated by passage of a storm system during 20 to $21 \mathrm{March}$, which resulted in mixing of the water column within the harbor and in SM Bay (Fig. 3). Surface temperatures that had been lowered by the storm began to increase again following the storm, especially within the northern basin, and the water column began to re-stratify during the last week of March (Fig. 3). Dissolved oxygen levels after the storm returned to more normal levels at the 3 harbor locations $\left(>3 \mathrm{ml} \mathrm{l}^{-1}\right)$ but remained highly variable, while the surface waters of SM Bay showed significant increases in dissolved oxygen following the mixing event (Fig. 3). 


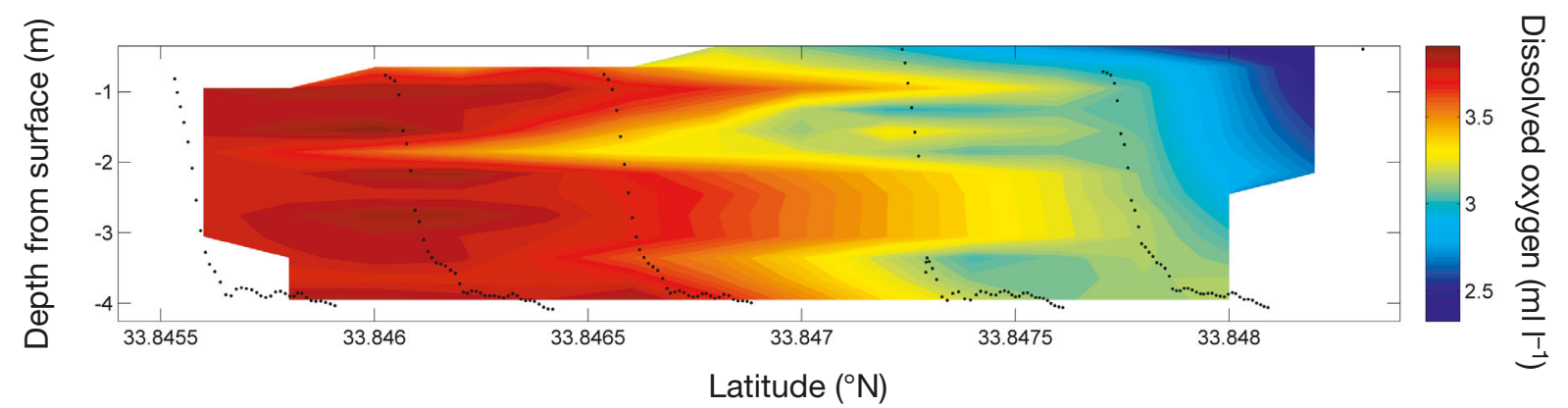

Fig. 4. Profiles and resulting contour plots of dissolved oxygen along a south-to-north transect in the outer harbor region of King Harbor on 25 March. The downward vertical profiles $(n=5)$ were obtained using the AUV EcoMapper. $\bullet$ : profile data points

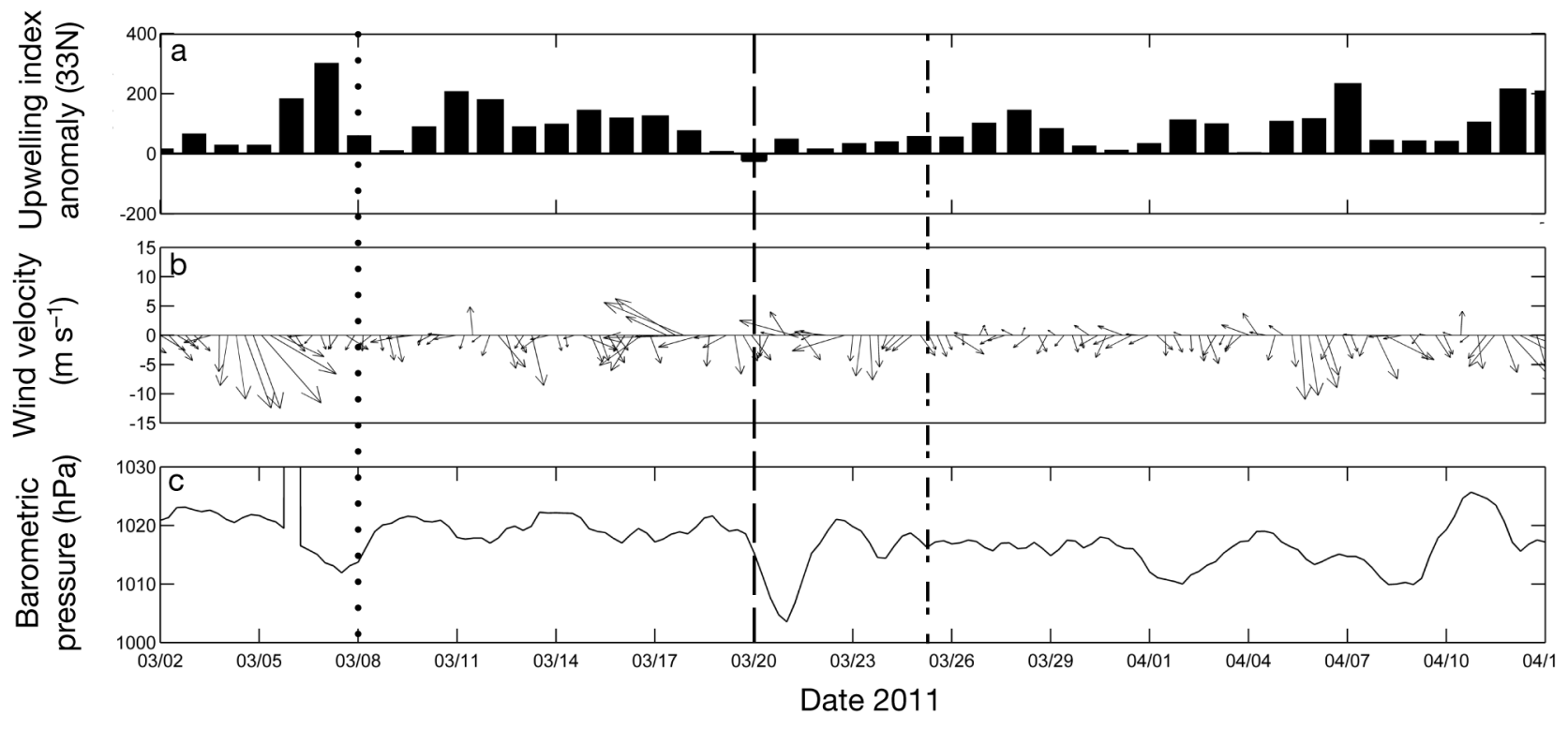

Fig. 5. Meteorological data for Southern California and Santa Monica (SM) Bay. (a) Daily upwelling index anomaly for the northeast Pacific was derived from surface pressure gradients for the $33^{\circ} \mathrm{N}$ region. Positive values represent equator-ward wind stress and upwelling favorable conditions. Negative values indicate downwelling. (b) Wind speed and direction and (c) barometric pressure were observed at NDBC buoy $46025\left(33.749^{\circ} \mathrm{N}, 119.053^{\circ} \mathrm{W}\right)$. Wind direction is indicated by arrow direction from true north, with negative arrows indicating upwelling-favorable winds. Vertical black dotted, dashed, and dotdashed lines indicate the first reported day of fish mortality (8 March), initiation of storm-mediated mixing on 20 March, and date of the AUV transect (25 March), respectively

AUV profiles from 25 March indicated low oxygen water within the northern basin, with values $<3 \mathrm{ml} \mathrm{l}^{-1}$ spreading out into the outer harbor region (Fig. 4), especially near the surface and at depth. Overall, dissolved oxygen concentrations increased from north to south in the outer harbor, while the water just outside of the southern basin location was $>3.5 \mathrm{ml} \mathrm{l}^{-1}$ throughout the water column.

Rapid reduction of dissolved oxygen within King Harbor on 7 March corresponded with a peak flow of $\sim 300 \mathrm{~m}^{3} \mathrm{~s}^{-1}$ (per $100 \mathrm{~m}$ coastline) in the upwelling index anomaly (Fig. 5a), as determined by surface pressure gradients for the $33^{\circ} \mathrm{N}$ region of Southern California. Equator-ward, upwelling- favorable winds were dominant, and wind speeds were elevated during this time, with sustained speeds in excess of $15 \mathrm{~m} \mathrm{~s}^{-1}$ (Fig 5b). Local evidence of upwelling was apparent as decreased temperatures within the harbor, at a nearby pier monitoring site, and within SM Bay (Fig. 2a,e) and slight increases in salinity (Fig. 2b) in both the northern and southern basins of King Harbor in the days preceding and during the fish kill event. A low pressure storm system on 20 to 21 March brought increased wind speeds (Fig. 5c) and significant precipitation. Averaged daily rainfall for this period was estimated at $7.32 \mathrm{~cm}$, accounting for $>71 \%$ of the total precipitation in the month of March and 
Table 1. Chlorophyll a $\left(\mu \mathrm{g} \mathrm{l}^{-1}\right)$, particulate (pDA) and dissolved domoic acid (dDA), and particulate saxitoxin (pSTX) concentrations for stations in King Harbor: the northern basin (NB), southern basin (SB), and outer harbor $(\mathrm{OH})$. Whole seawater toxin concentrations are given as $\mathrm{ng} \mathrm{ml}^{-1}$. Fish toxin concentration ranges $\left(\mathrm{n}=3\right.$ ) are indicated $\left({ }^{\mathrm{a}}\right)$ and are given in $\mu \mathrm{g}$ toxin $\mathrm{g}^{-1}$ body weight; -: samples that were not run; dates given as mm/dd/yy; bd: below detection limits

\begin{tabular}{|lccccc|}
\hline Date & Location & Chl & pDA & dDA & pSTX \\
\hline $02 / 08 / 11$ & NB & 1.0 & bd & bd & bd \\
& SB & 0.9 & bd & bd & 0.003 \\
$02 / 15 / 11$ & NB & 2.4 & bd & bd & 0.110 \\
& SB & 0.4 & bd & bd & - \\
$02 / 23 / 11$ & NB & 0.8 & bd & bd & 0.005 \\
& SB & 1.4 & bd & bd & 0.006 \\
$03 / 02 / 11$ & NB & 1.1 & bd & bd & 0.110 \\
& SB & 0.6 & bd & bd & 0.003 \\
$03 / 08 / 11$ & NB & 1.0 & bd & bd & bd \\
& SB & 1.8 & bd & bd & 0.004 \\
& Fish (stomach) & na & $5.25-72.20^{\mathrm{a}}$ & - & - \\
& Fish (whole) & na & $0.10-0.43^{\mathrm{a}}$ & - & $0.002-0.006^{\mathrm{a}}$ \\
$03 / 10 / 11$ & $\mathrm{NB}$ & 2.0 & bd & bd & 0.003 \\
& $\mathrm{SB}$ & 2.0 & 0.09 & - & bd \\
$03 / 11 / 11$ & $\mathrm{NB}$ & 2.0 & bd & - & - \\
& $\mathrm{SB}$ & 2.0 & 0.10 & - & - \\
& OH & 2.0 & bd & - & - \\
$03 / 15 / 11$ & $\mathrm{NB}$ & 1.6 & bd & - & bd \\
& SB & 9.0 & bd & - & 0.009 \\
& OH & 2.1 & bd & - & - \\
& & & & & \\
\hline
\end{tabular}

$\sim 42 \%$ of the accumulated rainfall from January to August 2011. A significant decrease in salinity was observed (Fig. 2b), and vertical mixing of the water column and initial reoxygenation were apparent (Figs. 2c \& 3), likely through the effects of increased wind speed and diffusion of oxygen across the airsea interface.

Algal biomass, as indicated by in vivo chlorophyll a fluorescence, was low $\left(<2.5 \mathrm{\mu g} \mathrm{l}^{-1}\right)$ in surface waters in the weeks preceding the 8 March fish kill (Fig. 2d), and there was no evidence of increased sub-surface concentrations on that date (data not shown). The surface microphytoplankton community in King Harbor was dominated by members of the classes Euglenophyceae and, later, Dinophyceae (mainly members of the Prorocentrum genus) from February to early March, with few toxic taxa observed (Stauffer et al. in press). Qualitative net tows (20 $\mu \mathrm{m}$ mesh) from the northern and southern basin locations confirmed the observed absence of significant abundances of toxic taxa in the weeks preceding the fish kill event (data not shown).

Low concentrations $\left(\leq 0.11 \mathrm{ng} \mathrm{ml}^{-1}\right)$ of particulate saxitoxin were measured from whole water samples from the northern and southern basins from 8 Febru- ary to 8 March. Domoic acid concentrations in both the dissolved and particulate fractions were below the limits of detection $\left(0.1 \mathrm{ng} \mathrm{ml}^{-1}\right)$ within the harbor during this time period (Table 1). Fish stomach samples collected on 8 March, however, contained domoic acid at concentrations of 5.25 to 72.20 $\mu \mathrm{g} \mathrm{g}^{-1}$ body weight, while whole fish toxin contents were lower, at $\leq 0.40$ and $\leq 0.006 \mathrm{\mu g} \mathrm{g}^{-1}$ body weight for domoic acid and saxitoxin, respectively (Table 1). At the time of the fish kill, a substantial bloom of Pseudo-nitzschia spp. was observed offshore in the San Pedro Channel (Fig. 1), with chlorophyll a concentrations $>17 \mu \mathrm{g} \mathrm{l}^{-1}$ and particulate domoic acid at extremely high concentrations (up to $52.29 \mathrm{ng}$ $\mathrm{ml}^{-1}$; Table 2). Maximal dissolved domoic acid concentrations (9.48 ng $\mathrm{ml}^{-1}$ ) were measured in samples collected on 9 March but were below detection by 15 March, at which time concentrations of particulate domoic also fell to $<1 \mathrm{ng} \mathrm{ml}^{-1}$ (Table 2).

\section{DISCUSSION}

Dissolved oxygen conditions within King Harbor prior to the fish kill on 8 March were below saturation conditions but within the physiological limits

Table 2. Chlorophyll a $\left(\mu \mathrm{g} \mathrm{l}^{-1}\right)$, and particulate (pDA) and dissolved domoic acid (dDA) concentrations for stations in San Pedro Channel (SPC 1 to 4) and Santa Monica Bay (SMB). Toxin concentrations are given as $\mathrm{ng} \mathrm{ml}^{-1}$. Dates given as mm/dd/yy; -: samples that were not run; bd: below detection limit

\begin{tabular}{|lcrcc|}
\hline Date & Location & Chl & pDA & dDA \\
\hline 03/09/11 & SPC1 & 10.35 & 42.29 & 1.38 \\
& SPC2 & 14.28 & 40.36 & 9.48 \\
& SPC3 & 16.07 & 52.29 & 4.67 \\
& SPC4 & 16.41 & 0.57 & bd \\
$03 / 11 / 11$ & SPC1 & 17.40 & 17.50 & 3.65 \\
& SPC2 & 9.27 & 8.92 & 2.59 \\
& SPC3 & 6.45 & 7.14 & - \\
& SPC4 & 11.70 & 0.17 & - \\
& SMB & 6.40 & 0.28 & - \\
$03 / 15 / 11$ & SPC1 & 5.46 & 0.67 & bd \\
& SPC2 & 2.59 & 0.51 & bd \\
& SPC3 & 10.90 & bd & bd \\
& SMB & 2.94 & 0.06 & - \\
\hline
\end{tabular}


of Pacific sardine (Martinez-Porchas \& HernandezRodriguez 2010). Average dissolved oxygen concentrations at the northern and southern basin locations were 1.54 and $0.43 \mathrm{ml} \mathrm{l}^{-1}$ lower than the average for the period from May 2010 to June 2011, respectively. The inter-basin difference can be largely attributed to higher concentrations, in general, within the northern basin, ostensibly a result of time-periods when algal primary production in the northern basin yielded dissolved oxygen concentrations as high as $9.75 \mathrm{ml} \mathrm{l}^{-1}$ (compared to a maximum of $8.26 \mathrm{ml} \mathrm{l}^{-1}$ in the southern basin). Other environmental parameters, including temperature and salinity, were also within expected ranges and offered no insight into the potential causes for the mortality event that followed. Additionally, no evidence was found that algal-enhanced biological oxygen demand, high algal abundance, or toxins within the harbor played immediate roles in the mortality event, despite the historical coincidence between a fish kill in King Harbor during 2005 and a red tide in the harbor at that time. While an algal bloom may have contributed to the fish kill in 2005, our findings for the 2011 mortality event do not indicate a causative role for algal blooms or algal toxins.

Evidence for upwelling at the time of the fish kill indicated a potential connection between regional oceanography and the low oxygen concentrations observed from 7 to 9 March. Wind-driven upwelling has been shown to deliver cool, nutrient-enriched, and oxygen-deficient deep offshore waters of the California Current System to the surface coastal waters of the west coast of the United States (Grantham et al. 2004, Monteiro et al. 2008). Recent research has indicated a role for upwelled waters in the spread of hypoxic zones (Bograd et al. 2008, Chan et al. 2008) and, as a result, mortality events in the Pacific Northwest (Grantham et al. 2004) and inland seas (Marti-Cardona et al. 2008). Therefore, it is conceivable that upwelled, potentially oxygendeficient water may have entered King Harbor just prior to the mortality event, thus resulting in the under-saturated conditions observed by the in situ sensors. Upwelling may have further facilitated the mortality event through the shoreward propagation of frontal boundaries along which fish populations have been shown to congregate (Checkley \& Barth 2009) and/or which may have prevented the fishes' exodus from the harbor. Further support for upwelling in the King Harbor region just prior to the mortality event can be found in the nearly $2^{\circ} \mathrm{C}$ temperature decrease observed within the harbor and at nearby coastal monitoring sites during this period (Fig. 2e).
Studies have shown shoreward contractions in recent years of sardine migration (McFarlane et al. 2005) and habitat (Zwolinski et al. 2012) within the California Current system, suggesting a broad mechanism for large populations of sardine in near-shore waters during the time period of the present study. The failure of the sardines to leave the harbor in the days leading to and during the fish kill remains unexplained, however, as sardines have been shown to avoid waters with oxygen levels $<2 \mathrm{ml} \mathrm{l}^{-1}$ or $25 \%$ saturation (Kreiner et al. 2009). With evidence of upwelling, it is possible that avoidance of hypoxic upwelled water from outside the harbor (Eby \& Crowder 2002, Bell \& Eggleston 2005, Palsson et al. 2008) or congregation of fishes in conjunction with a shoreward-moving frontal boundary formed by an upwelling filament (Checkley \& Barth 2009) may have driven the fish into the northern basin (or prevented their exodus), where they attained very high densities (Bograd et al. 2008, Chan et al. 2008, Kreiner et al. 2009). Additionally, Robinson et al. (2007) have suggested that sardine may re-distribute themselves closer to the air-sea interface to better utilize atmospheric oxygen rather than leaving oxygen-depleted waters, and studies of other schooling clupeoid fishes have shown increased swimming speeds in response to gradual reductions in oxygen (Domenici et al. 2000). Taken together, these studies of fish ecology and physiology provide a tenable mechanism for the accumulation and persistence of such a large population of sardine within a restricted, near-shore harbor with sub-optimal concentrations of dissolved oxygen.

Sardine-specific rates of oxygen consumption vary from $0.09 \pm 0.024 \mathrm{ml} \mathrm{O}_{2} \mathrm{~g}^{-1}$ wet weight $\mathrm{h}^{-1}$ for non-feeding, swimming fish (Logerwell 2001), 0.09 to $0.38 \mathrm{ml} \mathrm{O}_{2} \mathrm{~g}^{-1} \mathrm{~h}^{-1}$ depending on temperature and feeding intensity (van der Lingen 1995), and 0.24 to $0.35 \mathrm{ml} \mathrm{O}_{2} \mathrm{~g}^{-1}$ wet weight $\mathrm{h}^{-1}$ depending on activity level of the fish (Lasker 1970). Combined with an estimated low-tide volume of the northern basin of $1.9 \times 10^{5} \mathrm{~m}^{3}$ and the reported mass of dead fish removed $\left(1.54 \times 10^{5} \mathrm{~kg}\right)$, calculations using these rates suggest that complete northern basinwide depletion of dissolved oxygen to lethal levels (from 3.1 to $0.1 \mathrm{ml} \mathrm{l}^{-1}$ ) was possible within $9.7 \mathrm{~h}$ for a population of actively swimming and feeding fish. When rates for non-feeding fish are used (e.g. Logerwell 2001), this time-scale increases substantially to $41.1 \mathrm{~h}( \pm 15)$; however, estimates based on reduced metabolic requirements and measured within laboratory enclosures are likely inappropriate for estimation of rates for an actively feeding, 
in situ population of sardine. Depletion of the oxygen content of the northern basin in $<10 \mathrm{~h}$ is consistent with the temporally resolved diel decreases recorded by the in situ sensors on 7 to 9 March in the northern basin (Fig. 2f). Diel patterns of school formation of Pacific sardine also correspond to increased metabolic activity of fish within a school during early morning (Kaltenberg \& Benoit-Bird 2009) and are consistent with observed dissolved oxygen drawdown in the early morning hours of 7 to 9 March and anecdotal reports of a large school of sardine in the northern basin of King Harbor prior to 8 March.

Algal biomass as indicated by chlorophyll a fluorescence within the harbor was low $\left(<2.5 \mu \mathrm{g} \mathrm{l}^{-1}\right)$ at the time of the fish kill, and furthermore, the observed rapid depletions of oxygen occurred at night, suggesting that oxygen re-generation via photosynthesis did not play a significant role. The flux of oxygen from the atmosphere into surface waters, however, may have been important, especially given the high wind speeds observed in conjunction with the upwelling event (maximum $15.3 \mathrm{~m} \mathrm{~s}^{-1}$; Fig. 5). Using hourly wind speed, temperature, salinity, and dissolved oxygen data from 7 to 9 March and the equations of Weiss (1970), the flux of oxygen into the surface waters of the northern basin varied between an estimated maximum and minimum of 2.9 (8 March, 03:00 h) and $0.5 \mathrm{ml} \mathrm{l}^{-1} \mathrm{~d}^{-1}(8 \mathrm{March}, 23: 00 \mathrm{~h})$, respectively. The continued decline in dissolved oxygen during this time, despite the potential positive flux of oxygen from the atmosphere, further supports local biological and oceanographic processes as significant forcing mechanisms in the initiation of the mortality event. It is therefore plausible that, given already reduced dissolved oxygen concentrations within the harbor, the presence and metabolic activities of a large school of sardine were sufficient to further reduce dissolved oxygen levels in the hydrodynamically restricted northern basin to lethal levels on the timescale observed.

While the fish kill can be attributed to the metabolic activities of the fish, coupled to the influx of potentially oxygen-deficient deep coastal water, unanswered questions remain regarding the potential role of algal neurotoxins in the demise of the fish. Analyses of dead fish collected on 8 March yielded detectable concentrations of domoic acid in gut contents and whole fish, yet domoic acid and the diatoms that produce it, Pseudo-nitzschia spp., were below detection limits within the harbor at the time of the fish kill (Stauffer et al. in press). The presence of toxin within the fish presumably reflected feeding by the sardine population within a toxic Pseudo-nitzschia spp. bloom taking place in offshore waters $(\sim 10 \mathrm{~km}$ WSW of King Harbor) during early March 2011, prior to the fish entering King Harbor. The domoic acid concentrations observed in the fish (Table 1) were below concentrations that were originally thought to produce neurological symptoms in fish (Lefebvre et al. 2001). However, the results of that study have recently been called into question (Lefebvre et al. 2012), and furthermore the toxin concentrations measured in the fish represent toxin values following some unknown period of depuration by live fish and a relatively short period of decomposition within the dead fish in King Harbor (presumably a maximum of several days of depuration/ decomposition). Therefore, the actual degree of initial exposure to domoic acid, and the potential effects of such exposure, remain undetermined.

The Pseudo-nitzschia sp. bloom observed offshore in the San Pedro Channel at the time of the fish mortality event yielded the highest concentrations of domoic acid associated with the phytoplankton community that have been observed to date in this region (Schnetzer et al. 2007, A. Schnetzer \& D. A. Caron unpubl. data). It should also be noted that low yet detectable levels of saxitoxin were measured both in whole fish and within the harbor environment at the time of the fish kill. Saxitoxins have been shown to inhibit aggression suppression in rainbow trout (Bakke et al. 2010), affect metabolic activity in brain sub-regions of the Atlantic salmon (Bakke \& Horsberg 2007), alter neuronal protein expression and behavior in killifish (Salierno et al. 2006), and result in decreased growth and increased paralysis and mortality of larval or juvenile zebrafish (Lefebvre et al. 2004), even at sublethal concentrations. Given that the effects of chronic exposure to domoic acid or saxitoxin or exposure to extremely high concentrations of either toxin on fish physiology, behavior, and navigation are still not completely clear (Bakke \& Horsberg 2007), and given that the toxin history of the fish must be considerably higher than values observed in the dead specimens that were analyzed in the present study, we speculate that it is conceivable that phycotoxin exposure may have played some role in the inability of the fish to leave the northern basin in the presence of extreme hypoxia.

The temporal and spatial relationships of dissolved oxygen among the harbor locations following the mortality event indicate that the nearanoxic water was largely confined to the most affected northern basin from which the greatest 
biomass of dead fish was removed. The temporal lag between hypoxia appearing in the northern basin, outer harbor, and southern basin (and lack of appearance in SM Bay) revealed a pattern of generalized transport of low-oxygen waters from the northern basin to the other harbor regimes during the days to weeks following the event (Fig. 3). The AUV transect on 25 March confirmed a gradient from high to low dissolved oxygen from south to north in the outer harbor (Fig. 4). Our observations were unable to uniquely identify hypoxic waters that may have been transported shoreward from SM Bay via upwelling, but our observations outside the harbor were not initiated until after the fish kill. It is expected that any signal from an upwelling event would have been transient and dissipated by that time due to relaxation of the upwelling conditions.

The high resolution observations in the present study were only possible through the maintenance of an in situ sensor network within the harbor. The ability to continuously monitor the ecosystem of King Harbor through its transition from health to hypoxia and back again allowed the investigation of the important role of oceanographic and meteorological processes in the development of, and initial recovery from, a hypoxia-driven fish mortality event in March 2011. The meteorologically based oceanographic process of wind-driven upwelling coincided with the fish kill and potentially played a role in reducing dissolved oxygen concentrations prior to the fish kill. The metabolic activities of a large school of sardine subsequently drew down what oxygen remained from the system, resulting in a significant mortality event given the limited spatial scale. Sensor measurements and subsequent sampling/analyses also established that neither an algal bloom nor algal toxins within the harbor were directly involved in the fish mortality.

A decreasing trend in oxygen content in the California Current system in recent decades (Bograd et al. 2008) and documented increases in shelf hypoxia along the west coast of the USA (Chan et al. 2008) suggest that fish kills, such as the one described here, as well as general benthosassociated and water column hypoxia, are likely linked to, and will increase in frequency with, changing climate and oceanography (Monteiro et al. 2008). Expansion of ocean observing efforts throughout coastal ecosystems will continue to improve our abilities to understand, model, and ultimately predict and mitigate such extreme mortality events in the future.
Acknowledgements. This publication was produced with support from the National Science Foundation (CCR0120778 and CNS-0960163), National Oceanic and Atmospheric Administration MERHAB Program (NA05NOS4781228), National Oceanic and Atmospheric Administration National Sea Grant College Program (NA10OAR4170058), and the California Natural Resources Agency. The authors thank members of the City of Redondo Beach Fire Department, the Los Angeles County Lifeguards, and the City of Redondo Beach for their assistance in harbor access and sample collection. The authors also acknowledge the Wrigley Institute for Environmental Studies and G. Bovin, specifically, for offshore sample collection, R. Schaffner for assistance in mapping, L. Winslow and P. Hanson for helpful discussions about oxygen flux calculations, and P. Connell and V. Campbell for assistance in processing samples. The comments of 4 anonymous reviewers contributed substantially to the improvement of this manuscript.

\section{LITERATURE CITED}

Anderson DM, Burkholder JM, Cochlan WP, Glibert PM and others (2008) Harmful algal blooms and eutrophication: examining linkages from selected coastal regions of the United States. Harmful Algae 8:39-53

> Backer LC (2009) Impacts of Florida red tides on coastal communities. Harmful Algae 8:618-622

> Bakke MJ, Horsberg TE (2007) Effects of algal-produced neurotoxins on metabolic activity in telencephalon, optic tectum and cerebellum of Atlantic salmon (Salmo salar) Aquat Toxicol 85:96-103

Bakke MJ, Hustoft HK, Horsberg TE (2010) Subclinical effects of saxitoxin and domoic acid on aggressive behaviour and monoaminergic turnover in rainbow trout (Oncorhynchus mykiss). Aquat Toxicol 99:1-9

> Balayla D, Lauridsen TL, Sondergaard M, Jeppesen E (2010) Larger zooplankton in Danish lakes after cold winters: Are winter fish kills of importance? Hydrobiologia 646: 159-172

Barboza T, Weiss KR (2011) Redondo Beach fish die-off: tests show oxygen levels at 'almost zero'. Los Angeles Times, Los Angeles, CA

Bell GW, Eggleston DB (2005) Species-specific avoidance responses by blue crabs and fish to chronic and episodic hypoxia. Mar Biol 146:761-770

> Bograd SJ, Castro CG, Di Lorenzo E, Palacios DM, Bailey H, Gilly W, Chavez FP (2008) Oxygen declines and the shoaling of the hypoxic boundary in the California Current. Geophys Res Lett 35, L12607, doi:10.1029/ 2008GL034185

> Bohnsack JA (1983) Resiliency of reef fish communities in the Florida Keys following a January 1977 hypothermal fish kill. Environ Biol Fishes 9:41-53

> Brownlee EF, Sellner SG, Sellner KG (2005) Prorocentrum minimum blooms: potential impacts on dissolved oxygen and Chesapeake Bay oyster settlement and growth. Harmful Algae 4:593-602

Burkholder JM, Mallin MA, Glasgow HB Jr (1999) Fish kills, bottom-water hypoxia, and the toxic Pfiesteria complex in the Neuse River and Estuary. Mar Ecol Prog Ser 179: 301-310

Burkholder JM, Glasgow HB Jr, Hobbs CW (1995) Fish kills linked to a toxic ambush-predator dinoflagellate: distri- 
bution and environmental conditions. Mar Ecol Prog Ser 124:43-61

Cetinic I, Toro-Farmer G, Ragan M, Oberg C, Jones BH (2009) Calibration procedure for Slocum glider deployed optical instruments. Optics Express 17:15420-15430

Chan F, Barth JA, Lubchenco J, Kirincich A, Weeks H, Peterson WT, Menge BA (2008) Emergence of anoxia in the California Current Large Marine Ecosystem. Science 319:920

> Chavez FP, Ryan J, Lluch-Cota SE, Ñiquen CM (2003) From anchovies to sardines and back: multidecadal change in the Pacific Ocean. Science 299:217-221

> Checkley DM, Barth JA (2009) Patterns and processes in the California Current System. Prog Oceanogr 83:49-64

$>$ Diaz RJ, Rosenberg R (2008) Spreading dead zones and consequences for marine ecosystems. Science 321: 926-929

> Domenici P, Steffensen JF, Batty RS (2000) The effect of progressive hypoxia on swimming activity and schooling in Atlantic herring. J Fish Biol 57:1526-1538

- Eby LA, Crowder B (2002) Hypoxia-based habitat compression in the Neuse River Estuary: context-dependent shifts in behavioral avoidance thresholds. Can J Fish Aquat Sci 59:952-965

Gannon DP, McCabe EJB, Camilleri SA, Gannon JG and others (2009) Effects of Karenia brevis harmful algal blooms on nearshore fish communities in southwest Florida. Mar Ecol Prog Ser 378:171-186

Glibert PM, Burkholder JM, Graneli E, Anderson DM (2008) Advances and insights in the complex relationships between eutrophication and HABs: preface to the special issue. Harmful Algae 8:1-2

> Grantham BA, Chan F, Nielsen KJ, Fox DS and others (2004) Upwelling-driven nearshore hypoxia signals ecosystem and oceanographic changes in the northeast Pacific. Nature 429:749-754

Hoyer MV, Watson DL, Wills DJ, Canfield DE (2009) Fish kills in Florida's canals, creeks/rivers, and ponds/lakes. J Aquat Plant Manag 47:53-56

> Kaltenberg AM, Benoit-Bird KJ (2009) Diel behavior of sardine and anchovy schools in the California Current System. Mar Ecol Prog Ser 394:247-262

Kemp WM, Boynton WR, Adolf JE, Boesch DF and others (2005) Eutrophication of Chesapeake Bay: historical trends and ecological interactions. Mar Ecol Prog Ser 303:1-29

Kim CS, Lee SG, Lee CK, Kim HG, Jung J (1999) Reactive oxygen species as causative agents in the ichthyotoxicity of the red tide dinoflagellate Cochlodinium polykrikoides. J Plankton Res 21:2105-2115

Koehn JD (2004) The loss of valuable Murray cod in fish kills: a science and management perspective. MurrayDarling Basin Commission, Canberra

Kreiner A, Stenevik EK, Ekau W (2009) Sardine Sardinops sagax and anchovy Engraulis encrasicolus larvae avoid regions with low dissolved oxygen concentration in the northern Benguela Current system. J Fish Biol 74: 270-277

La VT, Cooke SJ (2011) Advancing the science and practice of fish kill investigations. Rev Fish Sci 19:21-33

Lasker R (1970) Utilization of zooplankton energy by a Pacific sardine population in the California current. In: Steele JH (ed) Marine food chains. University of California Press, Berkeley \& Los Angeles, CA, p 265-284

Lefebvre KA, Dovel SL, Silver MW (2001) Tissue distribution and neurotoxic effects of domoic acid in a prominent vector species, the northern anchovy Engraulis mordax. Mar Biol 138:693-700

Lefebvre KA, Trainer VL, Scholz NL (2004) Morphological abnormalities and sensorimotor deficits in larval fish exposed to dissolved saxitoxin. Aquat Toxicol 66: $159-170$

> Lefebvre KA, Frame ER, Kendrick PS (2012) Domoic acid and fish behavior: a review. Harmful Algae 13:126-130

Litaker RW, Stewart TN, Eberhart BL, Wekell JC and others (2008) Rapid enzyme-linked immunosorbent assay for detection of the algal toxin domoic acid. J Shellfish Res 27:1301-1310

> Logerwell EA (2001) Metabolic rate of California Pacific Sardine estimated from energy losses during starvation. Trans Am Fish Soc 130:526-530

Lowe JA, Farrow DRG, Pait AS, Arenstam SJ, Lavan EF (1991) Fish kills in coastal waters 1980-1989. Strategic Environmental Assessments Division, Office of Ocean Resources Conservation and Assessment, National Ocean Service, National Oceanic and Atmospheric Administration, Washington, DC

Lugg J (2000) Fish kills in New South Wales. NSW Department of Primary Industries, Cronulla, New South Wales

Marti-Cardona B, Steissberg TE, Schladow SG, Hook SJ (2008) Relating fish kills to upwellings and wind patterns in the Salton Sea. Hydrobiologia 604:85-95

Martinez-Porchas M, Hernandez-Rodriguez M (2010) Estimation of the thermal ranges associated with the distribution of Sardinops sagax caeruleus, based on its thermal preference. Rev Biol Mar Oceanogr 45:537-540

McFarlane GA, Schweigert J, MacDougall L, Hrabok C (2005) Distribution and biology of Pacific sardines (Sardinops sagax) off British Columbia, Canada. Calif Coop Oceanic Fish Invest Rep 46:144-160

> McInnes AS, Quigg A (2010) Near-annual fish kills in small embayments: casual vs. causal factors. J Coast Res 26: 957-966

McLeay LJ, Page B, Goldsworthy SD, Ward TM, Paton DC, Waterman M, Murray MD (2009) Demographic and morphological responses to prey depletion in a crested tern (Sterna bergii) population: Can fish mortality events highlight performance indicators for fisheries management? ICES J Mar Sci 66:237-247

Monteiro PMS, van der Plas AK, Mélice JL, Florenchie P (2008) Interannual hypoxia variability in a coastal upwelling system: ocean-shelf exchange, climate and ecosystem-state implications. Deep-Sea Res I 55:435-450

Mulholland MR, Morse RE, Boneillo GE, Bernhardt PW and others (2009) Understanding causes and impacts of the dinoflagellate, Cochlodinium polykrikoides, blooms in the Chesapeake Bay. Estuaries Coasts 32:734-747

> Ogawa K (2002) Impacts of diclidophorid monogenean infections on fisheries in Japan. Int $\mathrm{J}$ Parasitol 32: 373-380

Oh C, Ditton R (2005) Estimating the economic impacts of Golden Alga (Prymnesium parvum) on recreational fishing at Possum Kingdom Lake (Texas). Texas Parks and Wildlife Department, Austin, TX

> Paerl HW, Pinckney JL, Fear JM, Peierls BL (1998) Ecosystem responses to internal and watershed organic matter loading: consequences for hypoxia in the eutrophying Neuse River Estuary, North Carolina, USA. Mar Ecol Prog Ser 166:17-25

Palsson WA, Pacunski RE, Parra TR, Beam J (2008) The 
effects of hypoxia on marine fish populations in southern Hood Canal, Washington. Am Fish Soc Symp 64:255-280

Robinson CJ, Gomez-Aguirre S, Gomez-Gutierrez J (2007) Pacific sardine behaviour related to tidal current dynamics in Bahia Magdalena, Mexico. J Fish Biol 71:200-218

Ruuhijarvi J, Rask M, Vesala S, Westermark A, Olin M, Keskitalo J, Lehtovaara A (2010) Recovery of the fish community and changes in the lower trophic levels in a eutrophic lake after a winter kill of fish. Hydrobiologia 646:145-158

Salierno JD, Snyder NS, Murphy AZ, Poli M, Hall S, Baden D, Kane AS (2006) Harmful algal bloom toxins alter c-Fos protein expression in the brain of killifish, Fundulus heteroclitus. Aquat Toxicol 78:350-357

Schnetzer A, Miller PE, Schaffner RA, Stauffer BA and others (2007) Blooms of Pseudo-nitzschia and domoic acid in the San Pedro Channel and Los Angeles harbor areas of the Southern California Bight, 2003-2004. Harmful Algae 6:372-387

Southard GM, Fries LT, Barkoh A (2010) Prymnesium parvum: the Texas experience. J Am Water Resour Assoc 46: $14-23$

Editorial responsibility: William Kemp,

Cambridge, Maryland, USA
Stauffer BA, Schnetzer A, Gellene AG, Oberg C, Sukhatme GS, Caron DA (in press) Effects of an acute hypoxic event on microplankton community structure in a coastal harbor of southern California. Estuaries and Coasts

Strickland JDH, Parsons TR (1972) A practical handbook of seawater analysis. Bull Fish Res Bd Can 167, Ottawa

> Thronson A, Quigg A (2008) Fifty-five years of fish kills in coastal Texas. Estuaries Coasts 31:802-813

van der Lingen CD (1995) Respiration rate of adult pilchard Sardinops sagax in relation to temperature, voluntary swimming speed and feeding behaviour. Mar Ecol Prog Ser 129:41-54

Wagner EL, Boersma PD (2011) Effects of fisheries on seabird community ecology. Rev Fish Sci 19:157-167

Weiss RF (1970) The solubility of nitrogen, oxygen, and argon in water and seawater. Deep-Sea Res 17:721-735

Zwolinski JP, Demer DA, Byers KA, Cutter GR, Renfree JS, Sessions TS, Macewicz BJ (2012) Distributions and abundances of Pacific sardine (Sardinops sagax) and other pelagic fishes in the California Current Ecosystem during spring 2006, 2008, and 2010, estimated from acoustic-trawl surveys. Fish Bull 110:110-122

Submitted: October 21, 2011; Accepted: July 7, 2012

Proofs received from author(s): October 19, 2012 